\title{
Modern Indian Youth: Reasons and Result of Unrest and Core Agitation
}

\author{
Dr Kapil Dev Sharma \\ P.H.D, D.Litt. (English) Associate ProfessorCET IILM Greater Noida U.P
}

\begin{abstract}
This paper is highly concerned and mark approachive to present a sharp image of Indian youth and their different psychological reasons to adopt direct or indirect physical and mental unrest and agitation related to society, politics, administration, schools and universities.It is really a matter where the youth are vulnerable to outside influences \& imitate others but this does not mean that the youth only follow a way of destruction, assualt andget involved in terroistic activities. Somewhwer the question arises why? Should the youth alone be expected to conform to traditional moral values and lofty ideas? How can they look up to self-proclaimed political, religious and social leaders for inspiration?
\end{abstract}

Key words: Youth and their present thought, Issues and reforming psychology of youths

\section{Concept of youth unrest}

When we talk about "Unrest" simply it means "Present disturbed condition" Disturbed condition of present society, where most of time education comes first social unrest is the manifestation of collective disilluisionment \& frustration of group, if there is unrest among the students of onee educational institute oir university it is not perceived as the problem of student unrest as such. It is only when students all over the contry feel frustrated on such comman issues like examination,placement,jobs,cotent of any syllabus.Is it right to say that ther exists the problam of student unrest of our society? The emphasis in the concept of social unrest is on "collective frustration" and disillusionment on common social issues of the groups in the society.

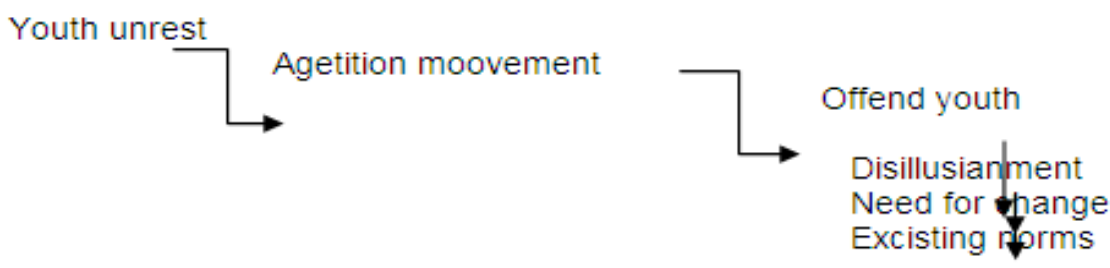

Major Characterstics of youth unrest

On the basis of selected definition it may be said that youth unrest is usually characerized by four important standards

1- Public concern

2-Change in the existing norms

3 -Active based on the feeling of injustice

4- Collective discontent

It will not be put of place to explain the concept of student indiscipline to elders or deviation from norms or rejecting to accept control. We should remember that a committee appointed by the UGC in 1960 present view of three major catagory of behaviour isn student indiscipline

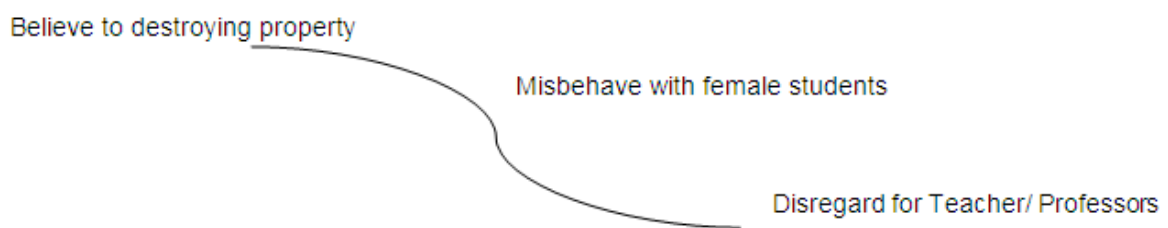

The UGC comittee of 1960 pointed out a number of reasons for student agitations

1 Economic cause for example a routine demand to reduce fees develope the support of increasing scholorship

2 Demand for changes in existing norms pertaining to admissions, teaching \& the process of admission 
3. Poor administration or functuning of college and universities

4. Unapropriate teaching in campus, hostal and other infrastruture.

In order to understand the more about youth agitations we may classify youth agitation into the following groups.

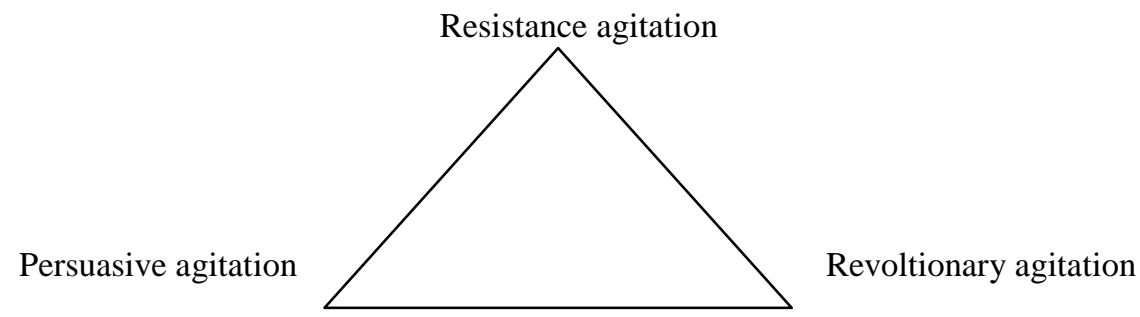

Resistance agitation-The main objective of resistance based agitation is to keep the power holder in their place. For example the decision of one university to show reduced marks on the marksheet, if one revalation the candidates marks are reduced, was resisted by the students through agitation in which ultimately forced the academics council of the university to decide the marks would not be reduced on revoluation. Students may resistthese masure. Somewhwer resistance agatation expresses the dismay and concern of the students at the direction in which the university is moving or acting

Persuasive agitation- Here youth attempts to change the attitute of the powers that be by discussing their problems with them across a table and making them accept their viewpoint. These agitation rannge from the relatively serious issues to significiant issuesto reality searious issuesthe anger and injustice expressed through this method not only series to arouse and mobilize popular support of passive youth or discontent into harmless emotional outlets.

Revolutionary agitations-The basic aim of revolutionary agitation is to bring sudden sweeping changes in the educational and social system.for example forcing authorities to decide that no student will be declared as failed but will be promoted to higher class and givren them opportunities to appear in the failed paper or subject till he or she clears it.Revolutionary leaders see basic changes as possible only after the existing system is overthrown and a new system is introduced in one go. Instances of revolutionary agitation can be illustrated by the youth agitation in china in 1987, the AASU agitation in Assam in 1994, Uttrakhand agitation in Uttarpradesh in 1994 and bodo agitation in Assam during 1989-96.

Youth Receptive to agitation- Normally there are five types of youth who take to agitational activities have been identified

1) Socially isoloted- Youth who feel alienated and cut off from the larger socity.

2) Unatteched to family- Youth who lack intimate ties with their families are encouraged to participate in agitation. Young persons with warm and satisfying family ties have no emotional needto join agitation.

3) Personally maladjusted- Youth who have failed to find a satisfying life role, for example those who have not developed an adequate interest in studies, aree unemployed or under-emlpyed or unsuccessful they join agitation because of an emotional need to fill the void in their lives.

4) Migrants- They have little chance of getting integrated into the larger community, joining agitation acts as refuge for them.

5) Marginals- Youth who are not fully accepted and integrated with their caste, religious, linguistic group feel uneasy, insecure and resentful. They find it difficult to resolve the discrepancy in self image and public image which neccessities them to join agitation to get some recognition.

Major theme on the cause of youth agitation

A number of theories related to youth agitation are always a part of discussion, usually two kinds of theories may be suggested to explain youth agitation.

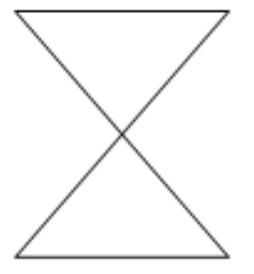

Psychological agitation Discontent

Socialogical agitation Personal maladjust 
It is probably true that without discontent amongst the youth, there will be no youth agitation or are contented and comfortable with what they have or what they are likely to have will have no interest in agitations, but the angry youth who feel victimized by outrageous justic, or those who feel even mildly annoyed with existing structure will collectively act to pressurize the power holder to bring some changes. On the other hand prsonal maladjustment theory sees agitatio as a refuge from personal failure. Hoffer in 1995 has also said that the kinds of people who are drawn to agitation and social mavements are the board, the creative who actully cannot create. Horton and Hunt in 1984 have also said that it is plasusible that young people who feel unfulfilled and maladjusted should be more attached to agitational activities, compartively those who are complacement and feel adjusted. In short the agitation supporters are mainly the frustrated misfits of society. It was Samuel stoffer in 1949 who propounded the relative deprviation theoty according to stoffer a group feels "deprived" if it is prevented from using or enjoying a gool. It regards as attractive relative deprviation is incerasind throughout most of the underdeveloped world. Youth in India also feel that lck of opportunities, unemployment, system of reservation, scope of higher education, even where the youth are beginning to get some of the things they eagerly desire.

These satisfactions come with an unberable slowness.Feelings of depriviation in youth easy to infer but difficult to measure and still more difficult to plot over a period of time.

The resourse mobilization theory- As if the words of Walshin1973 that without grievances and discontent there would be few agitation but mobilization is needed to direct this discontent into an effective agitation, but this theiry does not explain all kind of youth agitation if we classify agitations as persussive, revolutionary and resistant agitations the resource mobilization theory does not fit into resistance based agitation. These agitations succeed with organization further evidence for resourse mobilization is largely descriptive. In short we can say that so many variable are involved in the practice of youth agitation, but no one theory will even be conclusively established.

Procwss of the growth of agitation due to youth unrest

Youth agitation is the behaviour of the youth whose goal is neither injur to a person nor destructive of public property but social protest. It is a learned behaviour. The precondition of youth agitation is

1) To create colloctive consciuousness

2) To organize the youth to work for new programmes and new plans

3) To provide opportunities to young individuals to express their feelings and make some impact on the course of social change

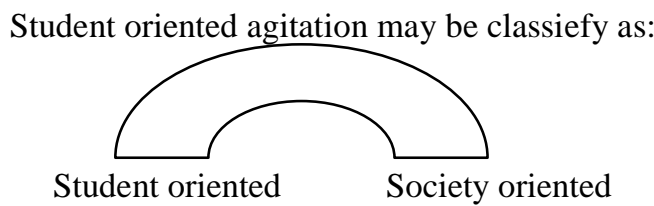

Student oriented agitation are actully problem orientad rather then value oriented. For example student will agitate for removal of particular Vice-chancellor of a university but they will never fight for a change in the system of selecting Vice-chancellor in university of India. Similarly in society oriented agitation they raise their voice against any illtreatment of any state administrator but they can't change system of state.

\section{Leadership quality of youth}

The leadership affect the intensity and direction of youth agitation and movement. A youth leader is responsible to establish an rsponsive, trysting, attentive relationship with the member of group. He senses their feelings and speakes their language. He develops a building of emotional rapport with the members by an impassioned reminder of their problem and grievance.He stimulates them to direct actively from one objective to another and suggesting different action to achieve goals. According to Sarkar"s ( 1960) study of the office holders and the king makers of student union in different universities has revealed that union leaders are mainly those who are with their financial background, who do not have high aspiraton, who have some political blocking, who are good orator and a fine manupulater as well. Mr. Shah has made his deep study of Osmania univerisity where he found that leaders are more better then an average class of common socity. They can easily efford comforts and manupulate other issues in such a stimulate manner.

Measures to control youth agitation

Overall the study of indian youth and unrest of youth which motivate them to follow the way of agitation, obiviousaly the force provoding unrest and agitation cannot be eliminated, how they might youth agitation be minimized? Do theories and research suggest way to control agitation? Ther is no doubt that an average man is individualistic, imaginative and competative. He only wants guidence so that his enthusaiasum coul be properly channalized.Youngsters should be taught to vent their anger. Ifa person bottels up his rage he 
has to find an outlet which may give him an opportunity to let off the stored stream.In psychiatric termonology thuis mean thatones accumulate aggrasive energy be it from frustration or from the building up of instinctual impulse, needs a realise. Parents have also to encourage their childerns realse of emotional tension in various kinds of activities. The adult world has to accept the facts that the youth problen cannot be solverd for them but with them. Therefore, co-operation of youth or student to be sought by parents, teachers, educational administrator, politicians and political parties should understand the problems and greviances of the youth and giving them logical guidelines. Each educational institutional institution must have an effective machanery to identify and settel student griveances. Such arrangements must not only start tackling problems after they flare up but most continuously strive to prevent incidents which lead to complications. Such bodies should be contionuously in session, if we talk about political boundaries; all political parties have to agree on a common code of conduct regarding student's participation in politics. It will prepare them for sholdering responsibilities in future for national develolpment.

\section{Conclusion}

There is no pppoint in exhorting students to keep away from politics and yet expect them to get enthusistacally involved in the process of building up of our socity. The question of the extant and patterns of students participation in the process of educational administration will have to be decide at the earliest. It is high experince that the vast youth power, which has been neglected and ignored, was harrased for development, removal of social injustic and achieving national collective goal. The need for creating a climate of hope, confidence and trust rather then coericion and confrontation has to be realized this finally initative has to be taken for mobilizing the young aspirents.

\section{References}

[1]. Huffer, Eric. The true beliver, Harper and Row New york- 1951

[2]. Horton, Paul B, and Hunt, Chester L, Sociology 6th Edn McGrawhill international book company Singapore 1984

[3]. Report of the UGC committee on "The problem of student indiscipline in India, UGC Delhi 1960

[4]. Shah, BV sociological bullitian, Bombay march 1968

[5]. Stoufferet al., The American soldier.Adjustment uring army life Vol-1 Princeton university 1959

[6]. Walsh Edward $\mathrm{j}$ “ Resourse mobilization and citizen protest in communities" in social problem October 1981

[7]. Dollod, Doob, Miller, Mower and sears, Frustration and aggression, Yale university press New haven 1993

[8]. Fesh back, S “ Aggression in myses, social psychological Mc Grawhill book company New York, 1970

[9]. Shills, Edward, Indian students rather sadhus then philistians” in encounter, Vol 19, Sep. 1961 